\title{
THE IMPACT OF REMITTANCES ON ECONOMIC GROWTH IN WESTERN BALKANS - A PANEL APPROACH
}

\author{
Predrag Trpeski \\ Faculty of Economics-Skopje, Ss Cyril and Methodius University \\ Predrag.Trpeski@eccf.ukim.edu.mk \\ Borce Trenovski \\ Faculty of Economics-Skopje, Ss Cyril and Methodius University \\ Borce.Trenovski@eccf.ukim.edu.mk \\ Gunter Merdzan \\ Faculty of Economics-Skopje, Ss Cyril and Methodius University \\ gjunter.merdzan@eccf.ukim.edu.mk \\ Kristijan Kozeski \\ Faculty of Economics-Skopje, Ss Cyril and Methodius University \\ kozeski@eccf.ukim.edu.mk
}

\begin{abstract}
The migration is one of the constitutive features of Western Balkans' historical specificity, which significantly changed Balkan societies in the last two centuries. One crucial effect of intensive emigration is high remittances. Cross-country analyses and evidence from household surveys suggest that migration and remittances reduce poverty in the origin communities. In addition, remittances lead to increased investment in education, health, and small businesses. The diaspora can be a source of capital, investment, knowledge, and technology transfer. The inflow of remittances can contribute to the economic development of the remittance-receiving country, provided that the country can use these funds to finance investments that will enable it to produce export or investment goods to replace imports. This paper examines the impact of remittances on economic growth in the Western Balkans (North Macedonia, Serbia, Albania, Kosovo, Montenegro, and Bosnia and Herzegovina) last two decades. The relationship between economic growth, remittances, final household consumption, domestic investments, and trade is examined through a panel approach. The paper uses annual data obtained from the World Bank World Development Indicators. The results of the empirical analysis help determine the relationship between remittances and economic growth and provide a solid base for policymakers to direct remittances into productive investments. The general conclusion for the region is the need to implement policies that will strengthen the financial system to enable a more significant positive impact of remittances from migrants on economic growth.
\end{abstract}

Keywords: Remittances, Economic Growth, Western Balkans

JEL classification: F22, F24, O47

\section{INTRODUCTION}

Immigration stimulates the economic growth of the recipient country in two ways. First, it expands the workforce and encourages more startup businesses. Second, it increases economic efficiency by supplying low- and high-skilled labor markets with more labor. Highly skilled migrants also assist in transferring advanced technology that reflects reduced production costs, 
reduces trade-related costs, and increases economic growth (Abdelbagi, 2016). However, the Western Balkans are suffering from substantial outgoing migration due to many problems faced and still being faced by the citizens in this region, such as political instability, unemployment, and poverty. As a result, many migrants from this region are causing a loss of human capital on the continent.

The Western Balkans region is aging rapidly, and its declining population is projected to continue. This trend is due to low fertility rates along with external migration. The regional fertility rate dropped from 3,9 to 1,6 children per woman in the period 1965-2015. Immigration is projected to reduce the region's population, though not as much as in the past. Bosnia and Herzegovina, which has the highest average age among the six countries, is expected to increase its average age from 41,5 in 2015 to 53,9 in 2065 - the second highest age in the world. In the absence of political or behavioral responses or changes in labor productivity, the simulations show that aging in the region will reduce labor force participation and average annual per capita income growth by 0,4 percentage points over the next 50 years. In 2010, more than $20 \%$ of the population born in North Macedonia lived abroad. In Bosnia and Herzegovina, and Albania, this figure was closer to $40 \%$. Massive external migration in the region has resulted in remittances of an average of $10 \%$ of GDP in the affected economies (World Bank Group, 2017).

On the other hand, emigrants from the Western Balkans contribute to the development of their countries through many channels. For example, remittance inflows from migrants generate income multipliers for receiving households, which become critical resources for local development. Remittances from these migrants also create more funding for other sectors, such as investment, trade, and human development. Cross-country data show a statistically significant negative correlation between labor force participation and remittances, although the link is not particularly strong. The correlation is stronger when we limit the sample to middleincome countries and even more so when taking only the Western Balkans. Remittances from abroad can affect the readiness for work and the readiness to take certain types of jobs, which leads to higher unemployment and possibly long periods of unemployment. Nevertheless, there is generally a positive relationship between remittances and unemployment in the Western Balkans (World Bank Group, 2017).

Remittances as part of GDP in the Western Balkans averaged about $9 \%$ in 2014, with the highest levels in Kosovo and Bosnia and Herzegovina. Remittances reach 20-25 \% of households in Kosovo and are estimated to account for more than $15 \%$ of GDP. As part of household income, remittances vary by country, with Kosovo having the highest level, followed by Albania. While these flows can increase income, support small business development, and alleviate poverty, their regular arrival can undermine the incentive to work. Remittances from abroad, together with the already large public transfers to households and individuals from the Western Balkans, increase non-labor incomes and reservation wages (World Bank Group, 2017).

Remittances, massive social security systems, and high wages in the public sector in the Western Balkans create discouraging factors for work. High non-labor income can create a perverse increase in activity by increasing the reservation wages, unemployment rates, and duration of unemployment. Higher wages and job security in the public sector may have increased reservation wages and created incentives to take private-sector jobs.

According to the latest Migration and Development Briefing (World Bank), in 2020, the officially recorded remittances flows to low- and middle-income countries reached $\$ 540$ billion, just 1,6\% below the total remittance of $\$ 548$ billion in 2019. Despite Covid-19, remittance flows remained resilient in 2020, recording a smaller decline than previously projected. The decline in registered remittance flows in 2020 was smaller than during the global financial crisis in $2009(4,8 \%)$. Also, the decline was far smaller than the decline in foreign 
direct investment (FDI) to low- and middle-income countries, which, without flows to China, fell by more than $30 \%$ in 2020. As a result, remittance flows to low- and middle-income countries exceeded the amount of FDI (\$ 259 billion) and foreign development assistance (\$ 179 billion) in 2020. The main drivers of the stable remittance flow included fiscal stimulus resulting in better-than-expected economic conditions in the host countries, the shift in cash flows in digital and from informal to formal channels, and cyclical movements in oil and exchange rates. As a result, it is estimated that the actual size of remittances, which includes formal and informal flows, is more extensive than officially reported data, although the extent of Covid-19's impact on informal flows remains unclear.

Therefore, this study aims to examine the impact of remittances on economic growth in the Western Balkans in the period 1996-2020. The rest of the paper is organized as follows: Part 2 reviews the literature, part 3 explains the data, and the empirical model and econometric technique are presented, part 4 is results and discussion, and the last part is intended for the conclusion. It is important to note that this paper examines only the direct effects of remittances on economic growth and does not aim to explore their indirect effects.

\section{LITERATURE REVIEW}

There are empirical studies that explain the impact of remittances on economic growth based on various theories and models. According to Jushi, et al., (2021), there are three main theories regarding the impact of remittances on development. The first theory has an optimistic view of the impact of remittances on economic growth. The second theory has a pessimistic view. The third theory emphasizes that remittances do not have a strictly positive or negative impact on economic growth, but this relationship is complex. Given the empirical literature and based on different theories, we believe that remittances are essential factors that positively impact economic growth, but it still depends on their use in specific countries and regions. We are testing this impact in the case of the Western Balkan countries.

Also, according to Rao \& Hassan, (2011), some papers examine the direct and others indirect short-term and long-term impacts of remittances on economic growth. Our paper examines the direct effects of remittances on economic growth. However, this is very different from examining the indirect macroeconomic effects of remittances, when, for example, the impact of remittances on economic growth through its volatility is explored (World Bank, 2006), by accelerating the development of the financial sector (Toxopeus \& Lensink, 2008), or through the real exchange rate (Rajan \& Subramanian, 2005). In addition, remittances can indirectly affect economic growth through education, human capital, domestic investment rate, and other important determinants of output growth.

Emigrant remittances are an essential source of funding for many developing countries. Chami, et al., (2005), Rao \& Hassan, (2011), and Barajas, et al., (2009), discuss the importance of remittances as a source of funding for developing countries. According to these authors, large inflows of remittances, as mentioned above, can potentially be expected to have significant effects on the growth rate of production capacity in recipient economies. Although a significant portion of the inflows is due to altruistic reasons for supporting the standard of living of family members, some are also motivated by monetary benefits and incentives offered by recipient countries. For example, non-resident deposits attract higher interest rates and are exempt from income tax in India and Pakistan (Rao \& Hassan, 2011).

Remittances also have effects on growth and well-being. However, there is little agreement and scant information in the literature on the impact of international migration and remittances. Adams \& Page, (2005), analyze a new data set on international migration, remittances, inequality, and poverty from 71 developing countries. Studies involving a larger sample of countries as Spatafora, (2005), have found evidence that remittances can help improve a 
country's development prospects, maintain macroeconomic stability, mitigate the impact of adverse shocks, and reduce poverty. According to the same study for many developing countries, remittances are a huge source of foreign exchange and have proven to be much more stable and less cyclical than other such sources.

As stated above, in addition to previous studies attempting to identify specific channels through which remittance inflows may affect growth, such as the effects of Dutch Disease (Nikas \& King, 2005), some studies discuss the direct effects of remittances on growth through regression of the growth rate on remittances and a set of control variables. Chami, et al., (2005), contrary to the general assumption in the literature and policymakers that remittances from immigrants play the same role in economic development as foreign direct investment and other capital flows; develop a remittance model based on the family economy, which implies that remittances are not profit-oriented but are compensatory transfers and should have a negative correlation with GDP growth. They test this model on new remittance panel data and find a robust negative correlation between remittances and GDP growth. Paper suggests that remittances may not be intended to serve as a source of capital for economic development. Faini, (2007), also uses the distance from major migrant destination countries as a crossregression remittance tool, using a sample of 68 countries with average data from 1980 to 2004 . The innovation in this study is that the author does not include the investment rate in the set of control variables, based on the fact that remittance flows could partially drive investments. In contrast to the previous study, the estimated total remittance ratio relative to GDP in Faini's regression through the ordinary least squares method was positive and significant. However, when the regression was assessed with instrumental variables, the remittance rate coefficient lost its statistical significance, although it remained positive.

Based on the above, remittances in the country of origin are the essence of the debate on migration and development in countries with many emigrants. However, the binary relationship between productive remittance investments (in agriculture, industrial development, education, health) and non-productive investments (housing, conspicuous consumption) is unclear and depends on the value courts on the nature of development. Moreover, the automation of remittances, distributed across hundreds of thousands of recipients, each makes its own decisions, disabling strategic planning for investing remittances in development priorities at the national level (Nikas \& King, 2005). So it can be concluded that how remittances will affect economic growth and development in a given economy largely depends on complementary infrastructure, services, favorable physical conditions (especially for agriculture), and a stable political and financial environment.

\section{DATA AND METHODOLOGY}

This chapter explains the data and presents the empirical model and econometric technique for examining the effects of remittances on economic growth. Date are taken for the six countries of the Western Balkans (North Macedonia, Serbia, Albania, Kosovo, Montenegro, and Bosnia and Herzegovina) for the period 1996-2020. They were collected from the World Bank World Development Indicators database. In order to make this analysis, the panel regression model is used in this paper. We use GDP per capita as a dependent variable, and remittances, final consumption, domestic investment, and trade are used for independent variables. Data on variables in their original form are shown in current USD, except the trade, \% of GDP (Table 1). For analysis, all variables are transformed into logarithms. Due to the lack of data for all countries for the entire time series, we work with unbalanced panel data and have 111 observations. The primary purpose of this study is to examine the direct effects of remittances on economic growth. 
Table 1: Description of the variables

\begin{tabular}{|c|c|c|}
\hline Variable & Explanation & Source \\
\hline $\begin{array}{l}\text { GDP per capita } \\
\text { (current US\$) }\end{array}$ & $\begin{array}{l}\text { GDP per capita is gross domestic product divided by } \\
\text { midyear population. Data are in current U.S. dollars. }\end{array}$ & $\begin{array}{l}\text { World } \\
\text { Development } \\
\text { Indicators, } \\
\text { World Bank }\end{array}$ \\
\hline $\begin{array}{l}\text { Personal } \\
\text { remittances, } \\
\text { received } \\
\text { (current US\$) }\end{array}$ & $\begin{array}{l}\text { Personal remittances comprise personal transfers in cash or } \\
\text { in-kind made or received by resident households to or from } \\
\text { nonresident households and compensation of employees. } \\
\text { Data are the sum of two items defined in the sixth edition of } \\
\text { the IMF's Balance of Payments Manual: personal transfers } \\
\text { and compensation of employees. Data are in current U.S. } \\
\text { dollars. }\end{array}$ & $\begin{array}{l}\text { World } \\
\text { Development } \\
\text { Indicators, } \\
\text { World Bank }\end{array}$ \\
\hline $\begin{array}{c}\text { Final } \\
\text { consumption } \\
\text { expenditure } \\
\text { (current US\$) }\end{array}$ & $\begin{array}{l}\text { Final consumption expenditure is the sum of household } \\
\text { final consumption expenditure (private consumption) and } \\
\text { general government final consumption expenditure (general } \\
\text { government consumption). Data are in current U.S. dollars. }\end{array}$ & $\begin{array}{l}\text { World } \\
\text { Development } \\
\text { Indicators, } \\
\text { World Bank }\end{array}$ \\
\hline $\begin{array}{l}\text { Gross fixed } \\
\text { capital } \\
\text { formation } \\
\text { (current US\$) }\end{array}$ & $\begin{array}{l}\text { Gross fixed capital formation includes: } \\
\text { - land improvements (fences, ditches, drains, and so } \\
\text { on); } \\
\text { - plant, machinery, and equipment purchases; and } \\
\text { - the construction of roads, railways, and the like, } \\
\text { including schools, offices, hospitals, private } \\
\text { residential dwellings, and commercial and } \\
\text { industrial buildings. } \\
\text { According to the } 1993 \text { SNA, net acquisitions of valuables } \\
\text { are also considered capital formation. Data are in current } \\
\text { U.S. dollars. }\end{array}$ & $\begin{array}{l}\text { World } \\
\text { Development } \\
\text { Indicators, } \\
\text { World Bank }\end{array}$ \\
\hline $\begin{array}{l}\text { Trade }(\% \text { of } \\
\text { GDP) }\end{array}$ & $\begin{array}{l}\text { Trade is the sum of exports and imports of goods and } \\
\text { services measured as a share of gross domestic product. }\end{array}$ & $\begin{array}{l}\text { World } \\
\text { Development } \\
\text { Indicators, } \\
\text { World Bank } \\
\end{array}$ \\
\hline
\end{tabular}

(Source: World Development Indicators Database, World Bank)

Econometrically, the general model we use for estimation when using panel data can be described as (Brooks, 2014):

$$
\gamma_{\mathrm{it}}=\alpha+\beta \mathrm{x}_{\mathrm{it}}+\mathrm{u}_{\mathrm{it}}
$$

where $\gamma_{\mathrm{it}}$ is a dependent variable, $\alpha$ is the intercept term, $\beta$ is a $\mathrm{k} \times 1$ vector of the parameters of the explanatory variables to be estimated and $x_{i t}$ is a $1 \times \mathrm{k}$ vector of observations of the explanatory variables, $\mathrm{t}=1, \ldots, \mathrm{T} ; \mathrm{i}=1, \ldots, \mathrm{N}$.

The simplest way to analyze panel data is by estimating pooled regression, which involves estimating one equation for all data so that the $\gamma$ database is arranged in a single column containing all observations for cross members and time series. Similarly, all observations of each explanatory variable are arranged in single columns in the matrix $\mathrm{x}$. In that case, this equation is estimated in the usual way using the ordinary least squares (MLS) method. Although this is a straightforward way to proceed and requires the estimation of as few parameters as possible, the procedure has some severe limitations. Most importantly, data aggregation in this way implicitly assumes that the mean values of the variables and the relationships between them are constant over time and across all cross-sections in the sample (Brooks, 2014). 
To solve this problem, we choose between two-panel evaluation approaches: fixed-effects and random-effects models. The simplest types of fixed-effect models allow the intercept in the regression model to differ between the cross-members, but not overtime, while all estimated slope coefficients are fixed both cross-sectionally and temporally.

The fixed effects model can be estimated using the following equation (Brooks, 2014):

$$
\gamma_{i t}=\alpha+\beta x_{i t}+\mu_{i t}+v_{i t}
$$

Where the error member $u_{i t}$, decomposes into an individual specific effect, $\mu_{i}$, and the "remainder disturbance", $v_{i t}$, which varies with time and terms (including everything that remains unexplained for $\gamma_{i t}$. We can count on $\mu_{i}$ as covering all variables which affect $\gamma_{i t}$ cross over, but do not differ over time.

An alternative to the fixed-effects model described above is the random-effects model. As with the fixed-effects model, the random-effects approach proposes different intercept coefficients for each member. However, these intercept coefficients are constant over time, assuming that the relationships between the explanatory and explained variables are the same crosssectionally and temporally.

However, the difference is that according to the random-effects model, it is assumed that the intercepts for each cross-member derive from a common a common intercept $\alpha$ (which is the same for all cross-members over time), plus a random variable $\epsilon_{i}$, which varies through the cross-members but is constant over time. $\epsilon_{i}$ measures the random deviation of the intercept of each member of the common intercept coefficient $\alpha$. We can write the panel model with random-effects as follows:

$$
\gamma_{\mathrm{it}}=\alpha+\beta \mathrm{x}_{\mathrm{it}}+\omega_{\mathrm{it}}, \quad \omega_{\mathrm{it}}=\epsilon_{\mathrm{i}}+\mathrm{v}_{\mathrm{it}}
$$

where $\mathrm{x}_{\mathrm{it}}$ is still a $1 \times \mathrm{k}$ vector of explanatory variables, but unlike fixed-effects, there are no dummy variables here to capture the heterogeneity (variation) in the cross-sectional dimension. Instead, it happens through members $\epsilon_{i}$. It should be noted that this framework assumes that the new error cross member $\epsilon_{i}$ has zero mean, is independent of the individual error member $\mathrm{v}_{\mathrm{it}}$, has a constant variance $\sigma_{\epsilon}^{2}$, and is independent of the explanatory variables $\mathrm{x}_{\mathrm{it}}$.

The random-effects model is often more appropriate than the fixed-effects model when the subjects in the sample can be considered randomly selected from the population. However, the fixed-effects model is more plausible when the subjects in the sample effectively make up the entire population (for example, when the sample covers all developed countries, emerging markets or developing countries according to their official classification by particular institution).

Also, because there are fewer parameters to be estimated with the random-effects model (no dummy variables) and therefore, degrees of freedom are preserved, the random effects model should produce a more efficient estimate than the fixed-effects model (Brooks, 2014).

However, the random-effects model has a significant drawback because it is only valid when the composite error member $\omega_{i t}$ is not associated with all explanatory variables. This assumption is stricter than the corresponding one in the case of the fixed-effects model because, with random-effects we require both $\epsilon_{i}$ and $\mathrm{v}_{\mathrm{it}}$ to be independent of $\mathrm{x}_{\mathrm{it}}$. This can also be understood as considering whether any omitted variable is not related to the explanatory variables included. Thus, the random-effects model can be used; otherwise, the fixed effect model is preferred. Finally, we perform the Hausman test to see which model in our analysis are recommended and display the results. 


\section{RESULTS AND DISCUSSION}

This section presents the results related to the impact of remittances on economic growth in the case of Western Balkans that are the subject of analysis in this research for 1996-2020. First, before presenting the results of the conducted empirical analysis, it is considered necessary to examine the integrative characteristics of the panel data, which implies the determination of the stationarity or non-stationarity of the variables. For this purpose, the LLC (Levin, Lin and $\mathrm{Chu}$ ) is used in this paper. Based on the results obtained from the conducted LLC test, it can be concluded that all of the variables are stationary at the level of $1 \%$ significance level.

Table 2: Results for the integrative characteristics of the variables used in the model

\begin{tabular}{|c|c|c|}
\hline Variable $^{\mid}$ & Statistics (LLC-test) & p-value of the statistics (LLC-test) \\
\hline InGDP $_{\text {p.c. }}$ & $-4,57811$ & 0,0000 \\
\hline InRemittances $_{\text {received }}$ & $-3,13067$ & 0,0009 \\
\hline InConsumption $_{\text {final }}$ & $-3,47775$ & 0,0003 \\
\hline InGFCF $^{\text {InTrade }}$ & $-4,67719$ & 0,0000 \\
\hline
\end{tabular}

(Source: Authors' calculations.)

Then, we evaluate the fixed effects model to see what information the "likelihood ratio" gives us from the "Redundant Fixed Effects Tests". The results of this test indicate that in this model it is permissible to impose fixed or random effects on the cross-members and not on the period. So, it is advisable to work with a model with fixed or random effects, rather than a pooled regression where all data is considered belongs to one entity without paying attention to the different characteristics between entities/cross-member entities. Next, we perform the Hausman test to decide which technique should be used in our model. The p-value of the Chisquare statistic is 0,0000 , i.e., it has a lower value of 0,05 , which means that we can reject the null hypothesis and find that, in our case, the fixed effects model is recommended.

The next step is to estimate the model, i.e. to determine the coefficients of the independent variables by imposing fixed effects on the cross-members in the model, and the following equation estimates it:

$$
\begin{aligned}
\operatorname{lnGDP}_{\text {p.c. }} \cdot 1996- & 2020 \\
& =\alpha+\beta_{1} \operatorname{lnRemittances}_{\text {received }}{ }_{1996-2020} \\
& +\beta_{2} \text { lnConsumption }_{\text {final }_{1996-2020}}+\beta_{3} \text { lnGFC }_{1996-2020} \\
& +\beta_{4} \text { lnTrade }_{1996-2020}+\mu+v_{1996-2020}
\end{aligned}
$$

\begin{tabular}{|c|c|c|c|c|}
\hline & Explanatory variables & Coefficient & t-statistics & p-value \\
\hline & InRemittances ${ }_{\text {received }}$ & $-0,057830^{* *}$ & $-2,553414$ & 0,0122 \\
\hline & InConsumption final & $1,006936^{* * *}$ & 37,80333 & 0,0000 \\
\hline & InGFCF & $0,075374^{* *}$ & 2,605607 & 0,0106 \\
\hline & InTrade & $0,201603^{* * *}$ & 4,760340 & 0,0000 \\
\hline & $\mathbf{a}$ & $-16,13444^{* * *}$ & $-67,80757$ & 0,0000 \\
\hline & $\mathbf{R}^{2}$ & 0,995176 & & \\
\hline & F-statistics & 2315,133 & & \\
\hline & p-value (F-stat) & 0,000000 & & \\
\hline
\end{tabular}

Table 3. Results for the estimated coefficients based on the model with fixed effects 
The estimate results indicate an appropriate level of fit of the model, i.e., the coefficient of determination $\mathrm{R}^{2}$ takes a value of $99,52 \%$, which indicates that the variations in the model are explained by the variables included in the model. Furthermore, the p-value of the F statistics of the evaluated model is $0 \%$, i.e., it is lower than $5 \%$ which means that the hypothesis that the explanatory variables together have a significant influence on the movement of the dependent variable can be accepted. Furthermore, the application of the Jarque-Bera test in the model also confirms the assumption of a normal distribution of the residuals. In our model, the p-value of the test statistics is $25,81 \%$, i.e., it has a higher value of $5 \%$; in that case, we cannot reject the null hypothesis that residuals follow a normal distribution. Therefore, according to the results obtained from the conducted diagnostic tests, it can be concluded that the model is well adapted, and the obtained results from the coefficients are objective and reflect the real relationship between the analyzed variables.

As expected, the results reveal that economic growth depends on final household consumption, domestic investment, and trade in the Western Balkans. All have a positive and significant impact on the economic growth of the Western Balkan countries. On the other hand, remittances have a significant but small negative impact on the economic growth in the same countries. As noted above, the Western Balkan countries suffer from vast migrants causing losses in human capital stocks. For example, educated and trained workers prefer to provide their skills abroad to receive a high salary, rather than what they would receive if they had worked in their country (Ziesemer, 2012). Based on this, it can be concluded that emigration negatively affects economic growth due to a lack of skilled and trained labor. However, these migrants can contribute positively to economic growth in certain countries or groups of countries through their remittances to countries of origin. Migrants' remittances help receive families and cover their living needs, such as food and clothing, so they tend to invest the rest in their children's health care and education. This will improve the way of life of remittance recipients and help build up human capital stocks in these countries by increasing the number of educated and healthier workers (Abdelbagi, 2016).

According to Amuedo-Dorantes, (2014), there are two main areas of concern at the macro level that find widespread empirical support in the literature: discouraging people from entering the workforce and the impact of remittances on domestic product prices and the exchange rate. The first category of problems refers to the potential reduction of labor supply, the development of conspicuous consumption patterns, and the inability to develop a culture of saving that can enable future investment and growth. However, despite declining labor supply after remittances, evidence of declining economic growth is rarer, and analyzes usually do not consider the long-term remittance flows in human capital, as mentioned earlier. Another impact of remittances at the macro level is their effect on the exchange rate by increasing the prices of domestically produced goods. Recalling the effects of Dutch Disease models or resource booms, some researchers argue that remittances can increase consumption of non-traded goods and prices of domestic products, reduce exports and undermine the country's competitiveness in world markets. There is evidence that these effects are most common in smaller economies, while they are more difficult to find in larger economies.

This is confirmed by The World Bank Group's analysis, (2017), that remittances, massive social protection systems, and high wage premiums in the public sector in the Western Balkans create discouraging factors for work. In addition, high non-labor income can create a perverse increase in inactivity by increasing the reservation wages, unemployment rates, and the public sector may have increased reservation wages and created disincentives to take up private-sector jobs. 


\section{CONCLUSION}

This study examines the direct impacts of remittances, final household consumption, domestic investment, and trade on economic growth in Western Balkans from 1996 to 2020. The study uses annual data obtained from the World Bank World Development Indicators database. The data are processed using panel technique, i.e., model with fixed-effects. Empirical results show that final consumption of households, domestic investment, and trade have a significant and positive impact on economic growth, while remittances have a significant but negative impact on economic growth in the Western Balkans in the analyzed period.

The negative relationship can be explained by two main areas of remittance impact on economic growth: the incentives created by remittance recipients to join the workforce and the impact on the exchange rate by increasing domestic product prices. As a result, production reduces exports and undermines the country's competitiveness in world markets. These effects are more common in smaller open economies such as the Western Balkans.

Remittances as part of household income vary by country, but while these flows may increase income, support small business development, and alleviate poverty, their regular arrival may undermine the incentive to work. Remittances, together with the already large public transfers to households and individuals from the Western Balkans, increase non-labor incomes and reservation wages.

Given the enormous potential benefits of remittances at the macro level, such as the contribution of remittances to the country's economic stability and creditworthiness, much more can be gained for economic growth and development through more effective management of this process. Therefore, this study is helpful for the academic and business community and policymakers that will help these countries limit emigration to retain qualified and trained staff in the Western Balkans. Furthermore, to introduce policies that develop the financial system, the positive effects can overcome the negative effects of remittances and positively impact economic growth.

\section{REFERENCES}

Abdelbagi, E., 2016. Migration, Remittances, Trade Opennes and Economic Growth in Africa: GMM Technique. Journal of Global Economics, 4(2).

Adams, R. H. \& Page, J., 2005. Do International Migration and Remittances Reduce Poverty in Developing Countries?. World Development, 33(10), pp. 1645-1669.

Amuedo-Dorantes, C., 2014. The Good and the Bad in Remittance Flows. IZA World of Labor, Issue 97.

Barajas, А. и др., 2009. Do Workers' Remittances Promote Economic Growth?. Bo: IMF Working Paper. H.M.:H.a., p. 22.

Brooks, C., 2014. Introductory Econometrics for Finance. Cambridge: Cambridge University Press.

Chami, R., Fullenkamp, C. \& Janjah, S., 2005. Are Immigrant Remittance Flows a Source of Capital for Development. IMF Staff Papers, 52(1), pp. 55-81.

Faini, R., 2007. Migration and Remittances: Impact on the Countries of Origin. Revue d'Économie du Développement, 15(2-3), pp. 153-182.

Jushi, E., Hysa, E., Cela, A. \& Panait, M. V. M., 2021. Financing Growth through Remittances and Foreign Direct Investment: Evidences from Balkan Countries. Journal of Risk and Financial Management, 14(3), p. 117.

Nikas, C. \& King, R., 2005. Economic Growth through Remittances: Lessons from the Greek Experience of the 1960s Applicable to the Albanian Case. Journal of Southern Europe and the Balkans, 7(2). 
Rajan, R. G. \& Subramanian, A., 2005. What Undermines Aid's Impact on Growth?. Bo: IMF Working Papers. H.M.:International Monetary Fund.

Rao, B. B. \& Hassan, G. M., 2011. A Panel Data Analysis of the Growth Effects of Remittances. Economic Modelling, 28(1-2), pp. 701-709.

Spatafora, N., 2005. Two Current Issues Facing Developing Countries. Bo: World Economic Outlook. Washington, DC.: International Monetary Fund.

Toxopeus, H. \& Lensink, R., 2008. Remittances and Financial Inclusion in Development. Bo: T. Addison \& G. Mavrotas, yp. Development Finance in the Global Economy. Studies in Development Economics and Policy. London: Palgrave Macmillan.

World Bank Group, 2017. The Western Balkans: Revving Up the Engines of Growth and Prosperity, Washington, DC: World Bank.

World Bank, 2006. The Development Impact od Workers' Remittances in Latin America, Vol. 2: Detailed Findings, Washington: World Bank.

Ziesemer, T. H. W., 2012. Worker Remittances, Migration, Accumulation and Growth in Poor Developing Countries: Survey and Analysis of Direct and Indirect Effects. Economic Modelling, 29(2), pp. 103-118. 